Available online at GSC Online Press Directory

GSC Biological and Pharmaceutical Sciences

e-ISSN: 2581-3250, CODEN (USA): GBPSC2

Journal homepage: https://www.gsconlinepress.com/journals/gscbps

(RESEARCH ARTICLE)

\title{
Prediction of active filing shelf in medical record unit - General hospital Dr. H. Soewondo Kendal 2020 - 2024
}

\author{
Prasetya Jaka ${ }^{1}$ and Isworo Slamet ${ }^{2, *}$ \\ 1. Department of Medical Record, Faculty of Health, Dian Nuswantoro University, Semarang, Indonesia. \\ 2. Department of Environmental Health, Faculty of Health, Dian Nuswantoro University, Semarang, Indonesia.
}

Publication history: Received on 20 November 2020; revised on 28 November 2020; accepted on 02 December 2020

Article DOI: https://doi.org/10.30574/gscbps.2020.13.3.0387

\begin{abstract}
General hospital Dr. H. Soewondo Kendal is a local government hospital. Improving medical support services, especially the quality of medical record archiving services, is essential to maintain the quality of hospitals in the context of good hospital standards. This study aims to predict the need for archive shelves between 2015-2019. The type of research used is descriptive with accidental sampling technique. Patient medical records were collected using a systematic sampling technique. The observation results showed that the average thickness of medical record documents was 0.85 $\mathrm{cm}$ based on measurements on 30 samples of medical record documents. The hospital has 48 shelves with 5 sub-shelves on each shelf. The length of the available archives is $525 \mathrm{~cm}$ and by 2024 a total of 37 shelfs will be needed. Modeling results based on linear regression equations have decreased medical record documents since 2015-2019 y $=-782.9 \mathrm{x}$ +30636 . However, the linear regression validation for the cumulative medical record documents for 2015-2019 shows an increase based on the regression equation $y=28439 \mathrm{x}+1112.2$, therefore it is necessary to immediately save the medical record document in an active state. The conclusion delivered by Dr. H. Soewondo Kendal does not need an additional archive shelf, but it does require inactive document storage.
\end{abstract}

Keywords: Medical records unit; Prediction of shelf needs; Medic record documents; Inactive document; Retention of medical records

\section{Introduction}

Regulation of the Minister of Health (Permenkes) RI Number. 749a / Menkes / Per / XII /1989 states that every health service facility is required to have an outpatient and inpatient medical record unit. [1] A medical record is a file containing notes and documents about the patient's identity, examination results, medication that has been given, and other actions and services provided to patients [2].

Processing of medical record document data which is closely related to the process of filing medical record documents. [3] Filing is a unit in the medical records department that is responsible for the storage, retention, and destruction of medical record documents. The filing unit is tasked with providing complete medical record documents so that it can facilitate the tracking of patient information data if needed at any time [4].

Unit Filing is responsible for the storage of medical record documents. The speed of taking medical record documents in the filing section also affects the service to patients. Fast and precise service with the support of existing facilities in the filing section, such as the availability of storage shelfs that are easily accessible by officers to make it easier to

\footnotetext{
* Corresponding author: Isworo Slamet

Department of Environmental Health, Faculty of Health, Dian Nuswantoro University, Semarang, Indonesia. 
retrieve medical record documents, the availability of sufficient shelves for patient medical record documents stored in active medical record filing documents so that patients will serve quickly. [5]

The frequency of entry and exit and the increase in medical record documents makes it necessary to predict the availability of ideal storage shelfs. Medical record documents that are stored on storage shelfs are not always kept in a long storage time, the document shelf will be full and not sufficient anymore so that it needs document retention 5 . If the filing space capacity is solid, it is necessary to sort the files that are already in the inactive category. Overcrowded shelves can complicate and slow down the process of storing and retrieving files, besides that, dense storage tends to be cluttered and damaged [6].

Based on the survey results at the general hospital Dr. H. Soewondo Kendal, the number of shelfs owned by the public hospital is 68 shelfs with each shelf having 5 sub-shelves with a centralized storage system, namely the storage of patient medical records in one place, both polyclinic visit records and notes while a patient is treated [7].

The numbering system used is the Unit Numbering System. This system only provides one medical record number for outpatients, inpatients, emergency patients, and newborns.

The medical record document structuring system uses the Digit Filing Terminal system, which is a system of synchronization by aligning medical record document folders based on the sequence of medical record numbers in the last two group numbers. (10) Archive Room in Dr. H. Soewondo Kendal has 3 floors for storing medical record documents. The 1st floor has tail number 579 for the 2 nd floor there is tail number 013 and on the 3rd floor there is tail number 2468 . The filler shelf is available at Dr. H. Soewondo Kendal has not yet collected all medical record documents because there are still many medical record documents, especially inpatient forms that have not been put on the storage shelf. At the time of taking documents, officers had difficulty retrieving the documents because the storage shelfs were too tight and not neatly arranged, especially on the 2nd floor archive shelf. H. Soewondo Kendal also has not retained medical record documents. General Hospital Dr. H. Soewondo Kendal every day has new patients who are influential with the need for shelves, so it is necessary to conduct research on "Prediction of Active Archives Shelf Medical Record Unit - Dr. H. Soewondo Kendal 2020 - 2024. The purpose of this study was to determine the prediction of the number of shelves needed in the filing unit of the General Hospital Dr. H. Soewondo Kendal in 2020 to 2024.

\section{Methods}

The type of research used is descriptive research with the method of observation [8]. The data collected in this study is to measure the dimensions of the document storage shelf including the length of the sub shelf, the width of the sub shelf and the height of the sub shelf. In addition, it also measures the dimensions of medical record documents which include the length, width and thickness of the document. The average thickness of medical record documents is based on measurements of 30 samples of medical record documents and the number of medical records from 2020 to 2024 . When the research was carried out from August 2017 to October 2017. The place of research was carried out at the Filling Unit, medical records department, Dr. H. Soewondo Kendal. The population in this study was 30 samples of medical record documents and the number of medical record documents from 2020 to 2024, medical record file storage shelfs totaling 48 shelves with 5 sub-shelves on each shelf and the available filing length was $525 \mathrm{~cm}$, while the sample used is a medical record document filling unit.

Sampling Techniques, outpatient medical record document shelves were taken by accidental sampling, namely, sampling was done by taking data that happened to exist at the time of the study. Meanwhile, the patient's medical record files were taken using systematic sampling [9].

The research variables observed were the average patient visit, the average thickness of the medical record file, the number of medical record file storage shelfs, the size of the medical record file storage shelf and the shrinkage of medical records [10].

\section{Results and discussion}

\subsection{Shelf Dimensions}

The General Hospital Dr. H. Soewondo Kendal has 2 types of shelves, namely iron shelves with a combination of wood and metal shelfs (gray) with the total number of shelfs is 48 and each shelf has 5 sub shelfs. 
Table 1 Dimensions of Filing Shelf 1 and 2

\begin{tabular}{|l|l|l|l|}
\hline No. & Filing Shelf Dimensions & Shelf 1 & Shelf 2 \\
\hline 1. & Material & $\begin{array}{l}\text { Iron shelf wood } \\
\text { combination }\end{array}$ & Iron shelf (gray) \\
\hline 2. & Sub Shelf Length & $105 \mathrm{~cm}$ & $105 \mathrm{~cm}$ \\
\hline 3. & Sub Shelf Width & $36 \mathrm{~cm}$ & $36,5 \mathrm{~cm}$ \\
\hline 4. & Sub Shelf Height & $40,5 \mathrm{~cm}$ & $35 \mathrm{~cm}$ \\
\hline
\end{tabular}

\subsection{Medical Record Documents}

The measurement results of the patient's medical record documents, dimensions of medical record documents, namely length: $34.5 \mathrm{~cm}$, width: $25.5 \mathrm{~cm}$ and the average thickness of medical record documents is $0.85 \mathrm{~cm}$ obtained from 30 samples of medical record documents from the total population: 141,437 documents medical records. The following is a table of the number of additional medical record documents [11].

Table 2 Addition of New Medical Record Documents for 2015 to 2019

\begin{tabular}{|l|l|l|l|}
\hline Time & Medical Record Documents & \% \\
\hline 2015 & 28.426 & $20,1 \%$ \\
\hline 2016 & 29.690 & $21,0 \%$ \\
\hline 2017 & 29.565 & $20,9 \%$ \\
\hline 2018 & 28.799 & $20,4 \%$ \\
\hline 2019 & 24.957 & $17,7 \%$ \\
\hline & Total & 141.437 & $100 \%$ \\
\hline
\end{tabular}

\subsection{Retention}

General Hospital Dr. H. Soewondo Kendal in 2015 to 2019, no retention was carried out due to constraints on the required costs. Arrangement of inactive medical record documents is calculated from at least the last 5 years from the date of the patient's last treatment. The goal is to reduce the burden of storing and storing assessment activities for the use of medical records for later preservation and destruction. [12].

Prediction of Number of Medical Record Documents for 2020 to 2024. In determining the prediction of the number of medical record documents from 2020 to 2024, it can be calculated by calculating the average number of additional medical record documents for new patients in the previous 5 years from 2015 to 2024 .

Table 3 Scale Series Analysis

\begin{tabular}{|l|c|l|l|l|}
\hline Time & Medical Record Document & $\mathbf{X}$ & $\mathbf{X Y}$ & $\mathbf{X}^{\mathbf{2}}$ \\
\hline 2015 & 28.426 & 2 & -56.852 & 4 \\
\hline 2016 & 29.690 & 1 & -29.690 & 1 \\
\hline 2017 & 29.565 & 0 & - & 0 \\
\hline 2018 & 28.799 & -1 & 28.799 & 1 \\
\hline 2019 & 24.957 & -2 & 49.914 & 4 \\
\hline Total & 141.437 & 0 & -7.831 & 10 \\
\hline
\end{tabular}

$Y_{n}=a \pm b \cdot x$ 
$\mathrm{a}=\frac{\sum Y}{n}=\frac{141437}{5}=28287,4$

$\mathrm{b}=\frac{\sum X Y}{\sum X^{2}}=\frac{-7831}{10}=-7831,1$

$Y_{n}=28287,4-783,1 . X$

Table 4 Prediction of the Number of New Patient Visits in 2020 to 2024

\begin{tabular}{|l|l|l|}
\hline Time & $\mathbf{Y}_{\mathbf{n}}=\mathbf{a} \pm \mathbf{b} \cdot \mathbf{x}$ & Result \\
\hline 2020 & $\mathrm{Y}=28287,4-783,1(3)$ & $25.938,1$ \\
\hline 2021 & $\mathrm{Y}=28287,4-783,1(4)$ & $25.155,0$ \\
\hline 2022 & $\mathrm{Y}=28287,4-783,1(5)$ & $24.371,9$ \\
\hline 2023 & $\mathrm{Y}=28287,4-783,1(6)$ & $23.588,8$ \\
\hline 2024 & $\mathrm{Y}=28287,4-783,1(7)$ & $22.805,7$ \\
\hline Total & & $121.859,5$ \\
\hline
\end{tabular}

\subsection{Available File Length}

In determining the need for archive shelves, it is necessary to know the length of the records available in one shelf so that the shelf needs to be predicted can be known. [13]. Shelf archive length is available at the General Hospital Dr. H. Soewondo Kendal:

$\mathrm{PP}=$ length of sub-shelf $\mathrm{x}$ number of sub-shelf

$=105 \times 5$

$=525 \mathrm{~cm}$

Data on the number of medical record documents in 2019 were 141437, medical record documents that will be added with predictions of additional medical record documents from 2020 to 2024 so that the calculation of the number of medical record documents in 2020 is 108,819.8 medical records, in 2021 it is 125, 170,5, the year 2022 is 141,012.3, the year 2023 is 1,56345, the year 2024 is $171,168,7$.

\subsection{Required Filing Length}

The required data filing length can be calculated by reducing the number of medical record documents in a certain year by the number of medical record documents stored then multiplying by the results of the file expansion. [14] General Hospital Dr. H. Soewondo Kendal in 2019 has not conducted retention so that more and more medical record documents are stored on the archive shelf.

Based on the results of measuring the thickness of 30 medical record documents, it was found that the average thickness of medical record documents was $0.85 \mathrm{~cm}$. (Table 5)

Table 5 Required Filing Length Calculation

\begin{tabular}{|l|l|l|l|}
\hline Time & $\begin{array}{l}\text { Medical Record } \\
\text { document }\end{array}$ & $\begin{array}{l}\text { Average Document } \\
\text { Thickness (cm) }\end{array}$ & Filing length (cm) \\
\hline 2020 & 25938,1 & 0,85 & 22047,4 \\
\hline 2021 & 25155 & 0,85 & 21381,8 \\
\hline 2022 & 24371,9 & 0,85 & 20716,1 \\
\hline 2023 & 23588,8 & 0,85 & 20050,5 \\
\hline
\end{tabular}




\begin{tabular}{|l|l|l|l|}
\hline 2024 & 22805,7 & 0,85 & 19384,8 \\
\hline
\end{tabular}

\subsection{Needs document shelf medical records}

Determination of the need for filing shelfs in 2020 to 2024 can be calculated based on the number of additional new patient medical record documents in 2015 to 2019 which are then calculated to obtain the required filing length data and available filing lengths, so that in calculating the shelf requirements for calculation results the required filing length divided by the available filing length [15].

Table 6 Prediction of Filing Shelf Needs in 2020 to 2024

\begin{tabular}{|l|l|l|l|l|}
\hline Time & $\begin{array}{l}\text { Medical Record } \\
\text { Document }\end{array}$ & $\begin{array}{l}\text { Filing length } \\
\text { required }\end{array}$ & $\begin{array}{l}\text { Filing lengths } \\
\text { available }\end{array}$ & Shelf Needs \\
\hline 2020 & 25938 & 22047,4 & 525 & 42 \\
\hline 2021 & 25155 & 21381,8 & 525 & 41 \\
\hline 2022 & 24371,9 & 20716,1 & 525 & 40 \\
\hline 2023 & 23588,8 & 20050,5 & 525 & 38 \\
\hline 2024 & 22805,7 & 19384,8 & 525 & 37 \\
\hline
\end{tabular}

\section{Discussion}

This research was conducted to determine the need for filing shelfs at Dr. H. Soewondo Kendal in 2020 to 2024. From the results of interviews with filing officers at the Medical Records Department, Dr. H. Soewondo Kendal uses a centralized storage system, the numbering system used is the Unit Numbering System, and the alignment system uses the Digit Filing Terminal. In the observation results in the filing room, there are 2 types of shelves, namely iron shelfs (gray) and wooden combination iron shelfs with 68 shelves and each shelf having 5 sub shelfs and the length of the sub shelfs is $105 \mathrm{~cm}$. In the measurement results, the iron shelf (gray) has a sub-shelf width of $36.5 \mathrm{~cm}$ and a sub-shelf height of $35 \mathrm{~cm}$, while on a combination of wood, the iron shelf has a sub-shelf width of $36 \mathrm{~cm}$ and a sub-shelf height of 40.5 $\mathrm{cm}$. obtained data the available archiving length is $525 \mathrm{~cm}$. The medical record document has a length of $34.5 \mathrm{~cm}$ and a width of $26.5 \mathrm{~cm}$, so that if the medical record document is inserted into the filing shelf, it can be neatly arranged because the width and height of the sub-shelf are in accordance with the length and width of the medical record document. The average thickness of medical record documents was 0.85. Retention in public hospital Dr. H. Soewondo in 2015 to 2019 has not been implemented due to constraints on costs, it is feared that it will cause a buildup of medical record documents so that the number of shelf needs will also continue to increase. The number of medical record documents from 2015 to 2019 was 141437. In the table for the addition of medical record documents from 2015 to 2019 it can be determined that the prediction of adding medical record documents from 2020 to 2024 is 2020 as many as 25938.1 medical record documents, year 2021 as many as 25155 medical record documents, in 2022 there were 24371.9 medical record documents, in 2023 there were 23588.8 medical record documents, in 2024 there were 22805.7 medical record documents with a total of 121859.5. The total medical record documents in 2019 will be added with the prediction of adding medical record documents in 2020-2024 so that the calculation of the length of filing required in 2020 is 22047.4 medical record documents, in 2021 there are 21381.8 medical record documents, in 2022 there are 20716, 1 medical record document, 20050.5 medical record documents in 2023, 19384.8 medical record documents in 2024.

The data for calculating shelf file predictions with the following details in 2020 requires 42 shelfs, in 2021 it requires 41 shelfs, 2022 requires 40 shelfs, 2023 requires 38 shelfs, 2024 requires 37 shelfs. Based on these calculations, the results show that there is no need for additional shelfs because the existing filing shelves are fulfilled, but if the RSUD Dr. H. Soewondo Kendal did not carry out retention and destruction, it would result in the increasing number of medical record documents and result in medical record documents piling up and the existing filing shelfs unable to accommodate the number of medical record documents properly. 


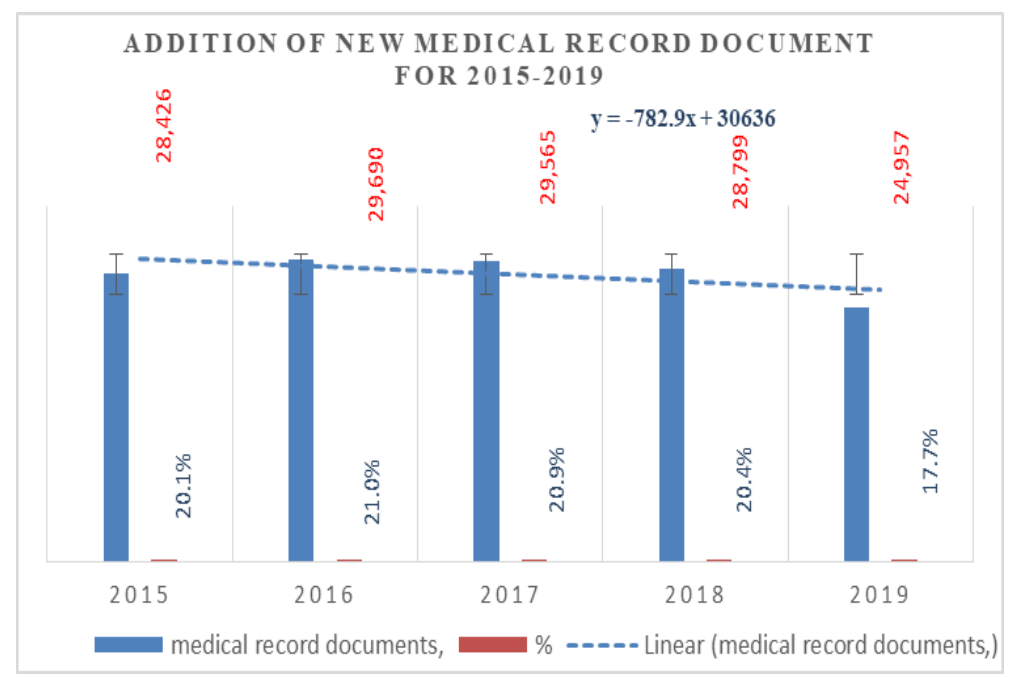

Figure 1 Addition of New Medical Record Documents for 2015 to 2019

Linear regression validation indicates that there is no increase in medical record documents, there is even a decrease in the linear equation $y=-782.9 x+30636$ this indicates a decrease in medical record documents in the hospital [16]

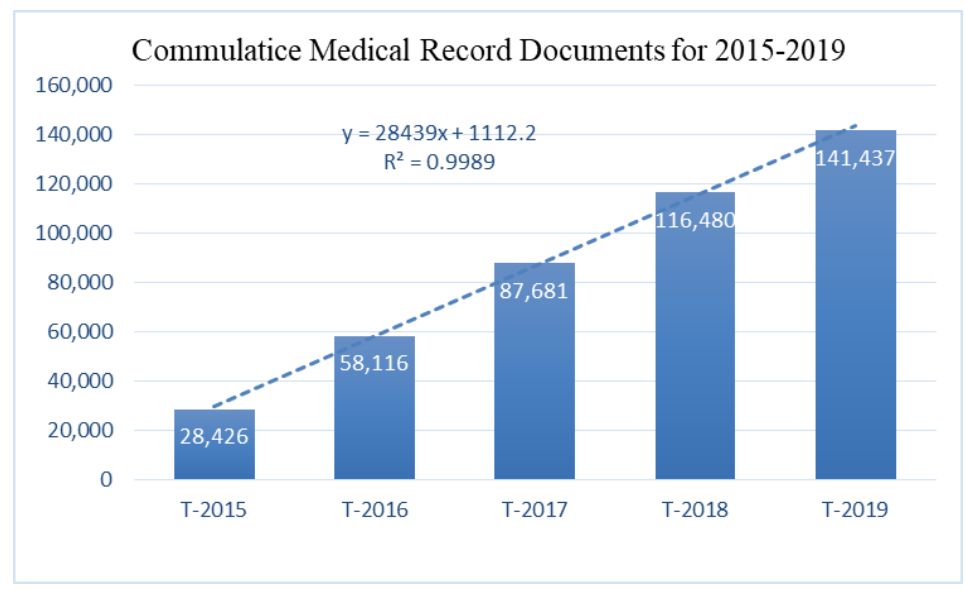

Figure 2 Cumulative Addition of New Medical Record Documents for 2015 to 2019

Linear regression validation for cumulative medical record documents in 2015-2019 showed an increase (y = 28439 $\mathrm{x}$ +1112.2 ), therefore retention is needed immediately so there is no accumulation of medical record documents.

\section{Conclusion}

The results of calculations and analysis at the General Hospital Dr. H. Soewondo Kendal does not require additional shelf filing, but retention of inactive medical record documents must be carried out immediately so that there is no accumulation of medical record documents so as not to disturb medical record officers in carrying out archiving tasks.

\section{Compliance with ethical standards}

\section{Acknowledgments}

The author is very grateful to the management of Dr. H. Soewondo Kendal so that the research was carried out well

\section{Disclosure of conflict of interest}

All authors state that this study has no competitive interest 


\section{Statement of informed consent}

Informed consent was obtained from all participants included in the study.

\section{References}

[1] Menteri Kesehatan. Peraturan Menteri Kesehatan Republik Indonesia Nomor : 749a | MENKES / PER / XII / 1989 Tentang Rekam Medis / Medical Records. 1989; 2.

[2] Gelb AW, Morriss WW, Johnson W, Merry AF. World Health Organization-World Federation of Societies of Anaesthesiologists (WHO-WFSA) international standards for a safe practice of anesthesia. Can J Anesth Can d'anesthésie. 2018; 65(6): 698-708.

[3] Organization WH. Classification of Digital Health Interventions v1. 0: A Shared Language to Describe the Uses of Digital Technology for Health. World Health Organization. 2018.

[4] Luthuli LP. Medical records management practices in public and private hospitals in Umhlathuze Area, South Africa. 2017.

[5] Dehnavi1 M, Baghini MS. National Medical Record Retention Laws. Spec J Med Res Heal Sci. 2019; 4(4): 35-48.

[6] Parsa Mahjob M, Farahabadi M, Dalir M. Medical record department problems (admission unit, filling unit, coding unit, statistical unit) in Motahari \& Peymani hospitals in 1387. J Jahrom Univ Med Sci. 2010; 8(1): 47-51.

[7] Miller SS. System for Electronically Recording and Sharing Medical Information. March 2017.

[8] Devhy NLP. Studi Deskriptif Kelengkapan Dokumen Rekam Medis Descriptive Study. The Completeness Of Medical Record Documents Ika Setya Purwanti1) Diah Prihatiningsih2). J Rekam Medis dan Inf Kesehat. 2020; $3(1)$.

[9] Aeny N, Eksan M, Tanjung A. The Effect of Service Price And Quality On Customer Satisfaction Online Transportation Services. J Res Business, Econ Educ. 2019; 1(1).

[10] Baumann FW, Roller D. Thingiverse: Review and analysis of available files. Int J Rapid Manuf. 2018; 7(1): 83-99.

[11] Agyeman CM, Binfoh KA, Lakhawat PS. Assessing the Dimensions of Hospital Records (Medical Records) in delivering quality of service to patients. PharmaTutor. 2018; 6(8): 1-8.

[12] Anna Asmyra. A Review of The Implementation Of Medical Recording Files at Baptis Kediri HospitaL Malang Institute of Administrative Science. 2019.

[13] Kohl L, Bénaud C-L, Bordeianu S. Finding shelf space in an academic library: A multifaceted approach. Tech Serv Q. 2017; 34(3): 268-282.

[14] Massengale J. Process of generating medical records. August 2017.

[15] Retno SA, Rangga P, Slamet I. In active filing management for preparation of use from legal aspects in general hospital Dr. H. Soewondo Kendal 2020. GSC Biol Pharm Sci. 2020; 13(1): 136-147.

[16] Azizah A, Permata A, Prasetya J, Isworo S. The Prediction of Return Quality Medical Record Documents William Booth Hospital, Semarang. Asian J Case Reports Med Heal. 2020: 11-22. 